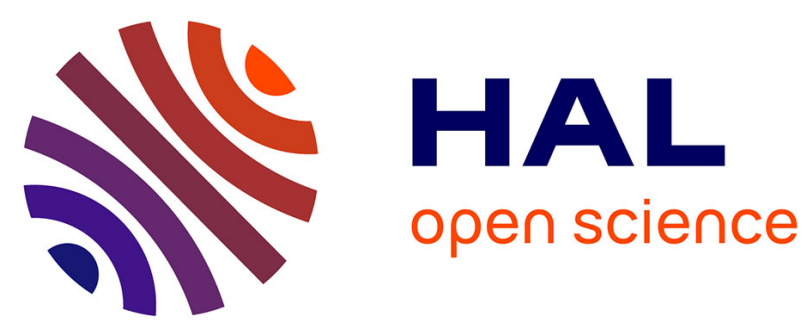

\title{
Reproductive phenology of Brazilian savannas and riparian forests: environmental and phylogenetic issues
}

\author{
Igor Silva, Danilo Silva, Gustavo Carvalho, Marco Batalha
}

\section{To cite this version:}

Igor Silva, Danilo Silva, Gustavo Carvalho, Marco Batalha. Reproductive phenology of Brazilian savannas and riparian forests: environmental and phylogenetic issues. Annals of Forest Science, 2011, 68 (7), pp.1207-1215. 10.1007/s13595-011-0071-5 . hal-00930804

\section{HAL Id: hal-00930804 https://hal.science/hal-00930804}

Submitted on 1 Jan 2011

HAL is a multi-disciplinary open access archive for the deposit and dissemination of scientific research documents, whether they are published or not. The documents may come from teaching and research institutions in France or abroad, or from public or private research centers.
L'archive ouverte pluridisciplinaire HAL, est destinée au dépôt et à la diffusion de documents scientifiques de niveau recherche, publiés ou non, émanant des établissements d'enseignement et de recherche français ou étrangers, des laboratoires publics ou privés. 


\title{
Reproductive phenology of Brazilian savannas and riparian forests: environmental and phylogenetic issues
}

\author{
Igor A Silva $\cdot$ Danilo $M$ da Silva . \\ Gustavo H de Carvalho • Marco A Batalha
}

Received: 16 January 2011 / Accepted: 9 May 2011 / Published online: 27 May 2011

(C) INRA and Springer Science+Business Media B.V. 2011

\begin{abstract}
- Introduction The reproductive phenology of plants is expected to be influenced by climatic factors and by the phylogenetic history of the species. In savannas, the peaks of flowering and fruiting are associated with climate seasonality. However, there is still a controversy about the reproductive phenology of plants in riparian forests, a vegetation type that does not experience a severe water shortage.

- Methods We tested whether the reproductive peaks in riparian forests are different from those of the savannas. We also tested if the number of species in flower is correlated with rainfall and day length. We sought evidence of phylogenetic signals in the reproductive periods of the species.

- Results Most of species in savannas and riparian forests flowered and fruited in the wet season. The number of flowering species was positively correlated with monthly rainfall and day length. However, we did not find phylogenetic signals in the reproductive periods.

- Conclusions The phenological pattern of riparian forests was similar to that of savannas. At the community level, the
\end{abstract}

\section{"Handling Editor: Gilbert Aussenac"}

Electronic supplementary material The online version of this article (doi:10.1007/s13595-011-0071-5) contains supplementary material, which is available to authorized users.

\section{A. Silva $(\triangle)$}

Departamento de Biologia Vegetal,

Universidade Estadual de Campinas,

PO Box 6109, Campinas 13083-970 SP, Brazil

e-mail: igor6cordas@yahoo.com.br

D. M. da Silva $\cdot$ G. H. de Carvalho $\cdot$ M. A. Batalha

Departamento de Botânica, Universidade Federal de São Carlos, PO Box 676, São Carlos 13565-905 SP, Brazil reproductive periods of plants may not be under phylogenetic constraints, as observed in forests under nonseasonal climate. Sun-related variables seem to be the main cues for the reproductive phenology of plants in savannas and riparian forests.

Keywords Cerrado $\cdot$ Flowering $\cdot$ Phenology $\cdot$ Phylogeny Seasonality

\section{Introduction}

Flowering and fruiting are important stages of the life history of plants, with both ecological and evolutionary consequences (Rathcke and Lacey 1985; Sakai 2001). The seasonal timing of flowering and fruiting, i.e. the reproductive phenology of plants, is directly associated with resource availability to animals and consequently has effects on herbivory, pollination and seed dispersal (Mduma et al. 2007; Stevenson et al. 2009; van Schaik et al. 1993). For these reasons, phenological synchronisation among individuals of a population is directly related to the reproductive success of the species (Sakai 2001).

The importance of phenological synchronisation for species survival may have led plants to link reproductive events to predictable environmental factors, such as rainfall, temperature, and day length (Borchert et al. 2002; Borchert et al. 2005). Some phenological studies of plant communities under seasonal climate have found that the reproductive phenology usually follows moisture availability (Batalha and Martins 2004; Boulter et al. 2006; Williams et al. 1999). However, it is still disputed whether climatic variables are the exclusive triggers of phenological events (Wright and Cornejo 1990). Other studies have also demonstrated that phenological events are under phyloge- 
netic constraints (Kochmer and Handel 1986; Staggemeier et al. 2010; Wright and Calderon 1995), because plant species commonly present a high degree of evolutionary stasis (Qian and Ricklefs 2004) and niche conservatism (Prinzing et al. 2001). Consequently, phylogenetically related plants are expected to have similar flowering and fruiting periods, i.e. a phylogenetic signal (sensu Blomberg et al. 2003) in their reproductive times.

In South America, the largest savanna region is the Brazilian cerrado, which once covered $22 \%$ of the land surface of the country (22 million ha), mainly in the central region (Gottsberger and Silberbauer-Gottsberger 2006). The cerrado is strongly seasonal, with a dry season, from April to September, and a wet season, from October to March, which define the growth patterns of plant species (Gottsberger and Silberbauer-Gottsberger 2006). Riparian forests occur commonly along rivers and streams crossing the cerrado landscape. Depending on the soil moisture availability along rivers, riparian forests include from permanent waterlogged vegetation (i.e. swamp forests) to rarely waterlogged vegetation (i.e. gallery forests; Naiman and Décamps 1997). Although riparian forests within cerrado areas are under the same seasonal regional climate, the drought in the winter is believed to have a small influence over the plant community, since riparian areas are influenced by elevated water tables or flooding and by the ability of the soils to hold water (Naiman and Décamps 1997). For this reason, riparian forests have a distinct flora (Felfili et al. 2001).

Phenological studies in cerrado have found that the flowering and fruiting of plants are markedly associated with rainfall periods. The flowering generally occurs year round with peaks at the late wet season (February and March) for herbaceous species, and at the late dry and early wet seasons (August and September) for woody species (Batalha and Mantovani 2000; Batalha and Martins 2004; Oliveira and Gibbs 2000). In riparian forests, however, the seasonality of phenological events seems to be less pronounced. Whereas in some riparian forests the phenological events of the woody species are uniform along the year (e.g. Gouveia and Felfili 1998), in others they seem to be also associated with rainfall, with peaks in the wet season (e.g. Funch et al. 2002).

Although phenological patterns in savannas have been well reported throughout South America (see Morellato 2003 and references therein), as far as we know there is a lack of studies considering the phylogenetic relatedness of plants. In this study, we assessed the reproductive events of 366 plant species in cerrado and riparian forest sites. We tried to answer whether the (1) soil moisture availability, (2) climatic variables, or (3) phylogenetic relatedness are the dominant determinants of the phenological patterns of the plant community. Several alternative outcomes can be predicted. First, if soil moisture is the limiting factor that determines the timing of flowering, then the riparian forest species are expected to flower and fruit in different periods than the cerrado species, as water is available to riparian forest plants year round. By contrast, cerrado species would be expected to have peaks of flowering and fruit that coincide with moisture availability. However, if other climatic variables determine the phenology of plants, then the number of species in flower in cerrado and riparian forest might be expected to be correlated with rainfall or day length. Finally, if the phylogenetic signal in the flowering and fruiting is the dominant determinant of flowering, then phylogenetically related species are expected to have similar phenological periods, regardless of water availability and seasonality.

To sum up, we addressed the following specific questions: (1) Do the riparian forest species present reproductive peaks different from the cerrado species? (2) Are the reproductive peaks of the herbaceous and woody species in riparian forests different from each other and from those in cerrado? (3) Is the number of species in flower related to precipitation or day length? (4) Do the closely related species have similar periods of flowering and fruiting?

\section{Methods}

\subsection{Study areas}

We carried out this study in a fragment of woodland cerrado of about 125 ha at the Federal University of São Carlos, São Paulo countryside, southeastern Brazil (21 ${ }^{\circ} 58^{\prime}-$ $22^{\circ} 00^{\prime} \mathrm{S}, 47^{\circ} 51^{\prime}-47^{\circ} 52^{\prime} \mathrm{W}$ ). Regional climate is markedly seasonal, with wet summers and dry winters (Cwa; Köppen 1931). The average annual rainfall is $1,339 \mathrm{~mm}$, and the average annual temperature is $22.1^{\circ} \mathrm{C}$. The soil is dystrophic on a flat topography, and the water table is reached $10 \mathrm{~m}$ below the surface. In the western portion of the cerrado fragment, there is a 50-m wide swamp forest in width along the Fazzari stream, which has $1.0 \mathrm{~m}$ in width and $0.3 \mathrm{~m}$ in depth approximately. The swamp forest presents a continuous canopy cover about $15 \mathrm{~m}$ high. The understory is composed by a mix of herbs, ferns and dwarf shrubs sparsely distributed.

In February 2007, we systematically placed five parallel transects in the swamp forest, two on one side of the stream, three on the other. In each transect, we established 20 contiguous plots of $25 \mathrm{~m}^{2}$. About $500 \mathrm{~m}$ distant from the swamp forest, we also systematically placed five parallel transects in a cerrado site, where we established 20 contiguous plots of $25 \mathrm{~m}^{2}$ in each transect. From February 2007 to January 2008, we visited monthly the two sites, where we observed all individuals of angiosperms in the 
plots. In the swamp forest, we used binoculars to search for flowers and fruits in the canopy of trees. The individuals at reproductive stage were identified in the field or collected for comparison with vouchers lodged at the herbarium of the Escola Superior Luiz Antônio de Queiroz. The observations were qualitative: for example, if at least one individual of a determined species was found producing flowers, the species was considered to be on its flowering period. We increased the phenological data with observations on trails of approximately $1.5 \mathrm{~km}$ within these sites of cerrado and riparian forests. Then, we classified the species in families according to a recent phylogenetic classification of angiosperms (Davies et al. 2004) and in growth forms according to Cornelissen et al. (2003). We considered the tree, shrub, climber, and palmoid species as belonging to woody component and the species with other growth forms as belonging to herbaceous component (see Electronic Appendix 1 in the Electronic supplementary material (ESM)).

To compare our results, we also analysed published flowering periods of woody species in a gallery forest at the Onça stream, in Brasília, central Brazil, approximately $15^{\circ} 50^{\prime} \mathrm{S}, 47^{\circ} 50^{\prime} \mathrm{W}$ (Oliveira and Paula 2001), comparing them with the flowering periods of woody species in a nearby woodland cerrado site in the Brasília Botanical Garden reserve, approximately $15^{\circ} 58^{\prime} \mathrm{S}, 47^{\circ} 51^{\prime} \mathrm{W}$ (Oliveira and Gibbs 2000). These nearby sites are also under a marked seasonal climate, with dry winters and wet summers (Aw; Köppen 1931).

Since the plant communities were sampled in different regional climates and with different methods, we first established a design for comparisons within Brazilian regions: we compared (1) the cerrado and swamp forest we sampled in southeastern Brazil (Cwa; Köppen 1931) and (2) the cerrado and gallery forest sampled by Oliveira and Gibbs (2000) and by Oliveira and Paula (2001) in central Brazil (Aw; Köppen 1931). Thus, we did not combine the data on the same vegetation type.

\subsection{Data analysis}

\subsubsection{Phenological data}

As our data were normally distributed (Shapiro-Wilk test), we used parametric circular statistics to analyse the number of species in flower and in fruit in each month in cerrado and in riparian forest. Circular statistics allow us to study seasonality in reproduction, being particularly useful in southern climates where flowering has not a logical starting point and reproducing events can occur almost continuously in an annual cycle (Morellato et al. 2010). Circular statistics can be used to characterise peaks in reproductive events and is recommended to formally compare and test hypotheses in plant phenology (Morellato et al. 2010). In our dataset, peaks are related to months that correspond to the average of the reproductive period and can be tested for differences in ecological dynamics between vegetation types. Our phenological data corresponded to one year cycle; therefore, they are better analysed with circular statistics (Morellato et al. 2010).

First, we applied the Rayleigh test of uniformity (Zar 1999 ) in which the 1 st of January corresponded to $15^{\circ}, 1$ st of February corresponded to $45^{\circ}$, 1 st of March corresponded to $75^{\circ}$, and so on, to answer whether there were reproductive peaks in cerrado and riparian forests. We also used this statistical test to answer whether the herbaceous and woody species flowered and fruited uniformly throughout the year. Then, to answer the first and second questions, we used the Watson-Williams test (Zar 1999) to evaluate whether the mean angles (i.e. the months that represent the average of the reproductive period) were different. We did these analyses with the 'circular' package (version 0.3-8, http://cran.r-project.org/web/packages/circular/) for the $\mathrm{R}$ environment (http://www.R-project.org).

\subsubsection{Climatic data}

To answer our third question, we correlated (1) the monthly rainfall (based on a 30-year record) in Brasília and in São Carlos, and (2) the average day length for each month to the number of herbaceous and woody species in flower in the cerrado and riparian forest sites. We estimated the Pearson's correlation coefficient and applied the $t$ test to evaluate if the correlation was different from zero (Zar 1999). We obtained the monthly rainfall data from records of the Brazilian Agricultural Research Corporation (Embrapa, http://www.bdclima. cnpm.embrapa.br/) and computed the day length with tools from The United States Naval Observatory (USNO, http://www.usno.navy.mil/USNO/astronomical-applications/ data-services/rs-one-year-world).

\subsubsection{Phylogenetic data}

To answer our last question, we first constructed a phylogenetic tree for the species sampled in São Carlos and another for the species sampled in Brasília with the Phylomatic software, a phylogenetic toolkit for the assembly of phylogenetic trees (Webb and Donoghue 2005). We included in these phylogenetic trees only those species classified at least to the genus level. The node ages of families were estimated from the dated angiosperm super-tree of Davies et al. (2004). We assigned branch lengths to genus and species of the phylogenetic tree by using the Branch Length Adjustment averaging algorithm of the Phylocom software package (version 4.0.1, http:// 
www.phylodiversity.net/phylocom/). The algorithm spaces undated nodes evenly between dated nodes in the tree. When a family node presented polytomies, we distributed the genera into their subfamilies following the last angiosperms relationship (Angiosperm Phylogeny Website, Version 9, http://www.mobot.org/MOBOT/research/APweb/). We assigned branch lengths of these genera by spacing undated nodes evenly above family node.

We calculated the phylogenetic distances from the estimated intervening branch length distances (measured in millions of years) between all species pairs with the Phydist module of the Phylocom software (version 4.0.1, http://www.phylodiversity.net/phylocom/). We estimated the mean angles of flowering and fruiting periods and calculated the difference between mean angles of all species pairs. Then, we compared the correlation coefficient between phylogenetic distances and mean angle differences of all species pairs to a null model, in which the differences in mean angles were randomised (Mantel test; Manly 2004). We also applied Mantel tests to compare the phylogenetic distances between genera and families with the differences between mean angles of genera and families.

\section{Results}

We analysed the flowering and fruiting periods of 196 species belonging to 56 families in the cerrado and of 97 species belonging to 47 families in the swamp forest, in southeastern Brazil. We also analysed the flowering period of 43 woody species belonging to 26 families in the cerrado and of 84 woody species belonging to 45 families in the gallery forest, in central Brazil (see Electronic Appendix 1 in the ESM). The results of these analyses are presented below.

\subsection{Uniformity test}

Considering all sampled plants in southeastern Brazil, the number of flowering and fruiting species was not uniformly distributed throughout the year (Fig. 1; Table 1; $P<0.05$ ). In general, most of the species in cerrado as well as in swamp forest flowered and fruited in the wet season (Table 1). However, the peaks of flowering and fruiting of the species in swamp forests occurred before those of the species in cerrado ( $F=0.33 ; P<0.01$ for flowering, $F=0.46 ; P<0.01$ for fruiting).

When we independently analysed the herbaceous and woody plants, the number of flowering and fruiting species was also not uniformly distributed throughout the year (Fig. 2; Table 2; $P<0.05$ ). In general, the peaks of flowering and fruiting of the herbaceous species occurred after those of the woody species in both vegetation types $(F<1.10 ; P<0.05$ for all comparisons). Most of the herbaceous species flowered and fruited at the end of the wet season, whereas most of the woody species flowered and fruited at the end of the dry season and at the beginning of the wet season (Table 2).

\subsection{Comparisons between cerrado and riparian forests within regions}

When we compared the flowering and fruiting patterns of both herbaceous and woody species between cerrado and swamp forest, the only significant pattern was in the fruiting peaks. The fruiting peaks of the herbaceous and woody species in the swamp forest were not different from those of the herbaceous and woody species in the cerrado (Table 2, $F=1.13$ for woody species, $F=0.54$ for herbaceous species, $P>0.05$ for both comparisons). In the southeastern sites, the flowering peaks of the herbaceous and woody species in the swamp forest occurred before those of the herbaceous and woody species in the cerrado $(F<0.50, P<0.05$ for both comparisons). By contrast, in central Brazil, the flowering peak of woody species in the gallery forest occurred after the flowering peak of woody species in the cerrado (Table 2; $F=13.25, P<0.01)$.

\subsection{Correlations between flowering and climatic variables}

The number of flowering species was not strongly correlated with climatic variables. Most of the correlations with the monthly rainfall and day length were not significant (Table $3 ; R^{2}<0.25, P>0.05$ ). Nevertheless, the number of flowering herbaceous species in the swamp forest was positively correlated with monthly rainfall $\left(R^{2}=\right.$ $0.73, t=5.26, P<0.01)$ and day length $\left(R^{2}=0.45, t=2.87\right.$, $P<0.01)$, and the number of flowering woody species in the cerrado was positively correlated with day length $\left(R^{2}=\right.$ $0.31, t=2.19, P=0.05)$, in southeastern Brazil.

\subsection{Phylogenetic signal test}

The comparison between phylogenetic distances and differences of mean angle of the flowering and fruiting periods of the species was not significantly correlated ( $r=0.004, P=0.336$ for flowering; $r=-0.014$ for fruiting, $P=0.773$ in southeastern sites and $r=-0.029$ for flowering, $P=0.995$ in central sites). When we considered the differences of mean angle of genera and families, we also did not observe significant correlations $(-0.05<r<0.06$, $P>0.05$ for all comparisons). Thus, we did not find a phylogenetic signal in the reproductive periods of plants in cerrado and riparian forest sites. 
Fig. 1 Proportion of species a flowering in the cerrado, $\mathbf{b}$ flowering in the swamp forest, c fruiting in the cerrado and $\mathbf{d}$ fruiting in the swamp forest, in southeastern Brazil (approximately, $22^{\circ} 00^{\prime} \mathrm{S}$ $\left.47^{\circ} 51^{\prime} \mathrm{W}\right)$

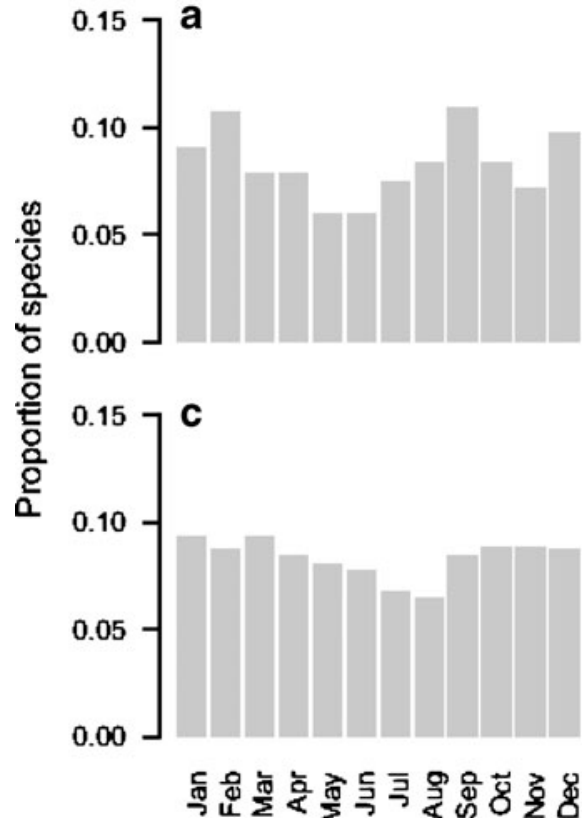

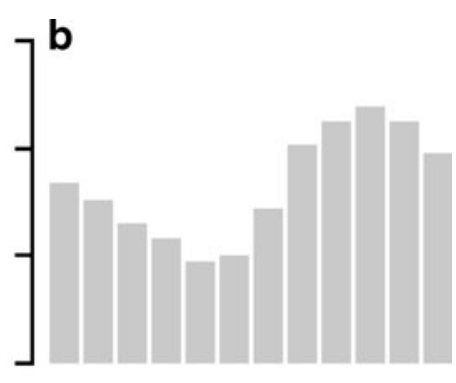

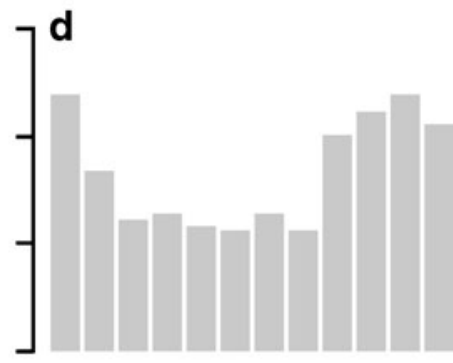

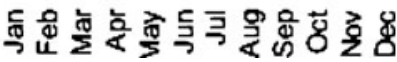

\section{Discussion}

\subsection{Reproductive peaks in the wet season}

The riparian forests had annual flowering and fruiting peaks. These phenological periods were in general similar to those found in cerrado, i.e. the species flowered and fruited predominantly in the wet season. There was no evidence from our data that the small seasonal variation in soil moisture in riparian forests influenced the reproductive periods of plants. However, we did not observe any strong correlations between the number of flowering species and climatic variables we considered or a phylogenetic signal in the reproductive periods of species.

In the absence of a phylogenetic signal, the cue to flowering is likely to be environmental. While we did not find any evidence of this relationship, this may be because several environmental factors are at work or we did not test for the appropriate environmental factor. The cerrado plants show a multitude of phenological strategies that are to a certain extent independent of rainfall and soil moisture (Monasterio and Sarmiento 1976; Sarmiento and Monasterio 1983). The phenology of riparian forest species also appear to respond weakly to soil moisture availability (Funch et al. 2002; Wright and Calderon 1995; Wright and Cornejo 1990). Thus, other factors such as sun-related variables (Borchert et al. 2005), could predominantly trigger flowering and fruiting in cerrado and riparian forests.

\subsection{Comparisons between cerrado and riparian forests}

Considering all species, the peaks of flowering and fruiting occurred in the wet season in both cerrado and riparian forest sites. In other seasonally dry communities (savannas: Williams et al. 1999; Batalha and Martins 2004; dry forests: Borchert et al. 2002) or even in communities with weak climatic variation (Atlantic rain forests: Morellato et al. 2000; gallery forests: Funch et al. 2002), there are also seasonal peaks of reproductive events in the late dry or early wet season. Although seasonally dry communities are under moisture seasonality, sun-related environmental factors, such as day length and insolation, seem to be the only reliable environmental cues for synchronisation of reproductive events, since they do not vary over the years (Borchert et al. 2005). Our results demonstrated some support for

Table 1 Rayleigh test of uniformity $(Z)$, mean angles (in degrees) of flowering and fruiting periods and the months that correspond to the average of the reproductive period distributions in cerrado and swamp forest sites in São Carlos, southeastern Brazil

\begin{tabular}{llcrr}
\hline Vegetation type & Phenological data & Mean angle & Month & $Z$ \\
\hline Cerrado & Flowering & 320.4 & November & 0.077 \\
Cerrado & Fruiting & 3.5 & January & 0.031 \\
Swamp forest & Flowering & 281.2 & October & 0.053 \\
Swamp forest & Fruiting & 312.7 & November & 0.199 \\
\hline
\end{tabular}


Fig. 2 Proportion of $\mathbf{a}$ herbaceous and $\mathbf{b}$, $\mathbf{c}$ woody species flowering in cerrado, $\mathbf{d}$ herbaceous and $\mathbf{e}, \mathbf{f}$ woody species flowering in riparian forest, $\mathbf{g}$ herbaceous and h woody species fruiting in cerrado and $\mathbf{i}$ herbaceous and $\mathbf{j}$ woody species fruiting in riparian forest in $\mathbf{a}, \mathbf{b}, \mathbf{d}, \mathbf{e}, \mathbf{g}-\mathbf{j}$ southeastern Brazil (approximately, $22^{\circ} 00^{\prime} \mathrm{S}, 47^{\circ} 51^{\prime} \mathrm{W}$ ) and c, $\mathbf{f}$ central Brazil (c approximately, $15^{\circ} 58^{\prime} \mathrm{S}, 47^{\circ} 51^{\prime} \mathrm{W}$; Oliveira and Gibbs 2000; f approximately, $15^{\circ} 50^{\prime} \mathrm{S}$, $47^{\circ} 50^{\prime} \mathrm{W}$; Oliveira and Paula 2001)

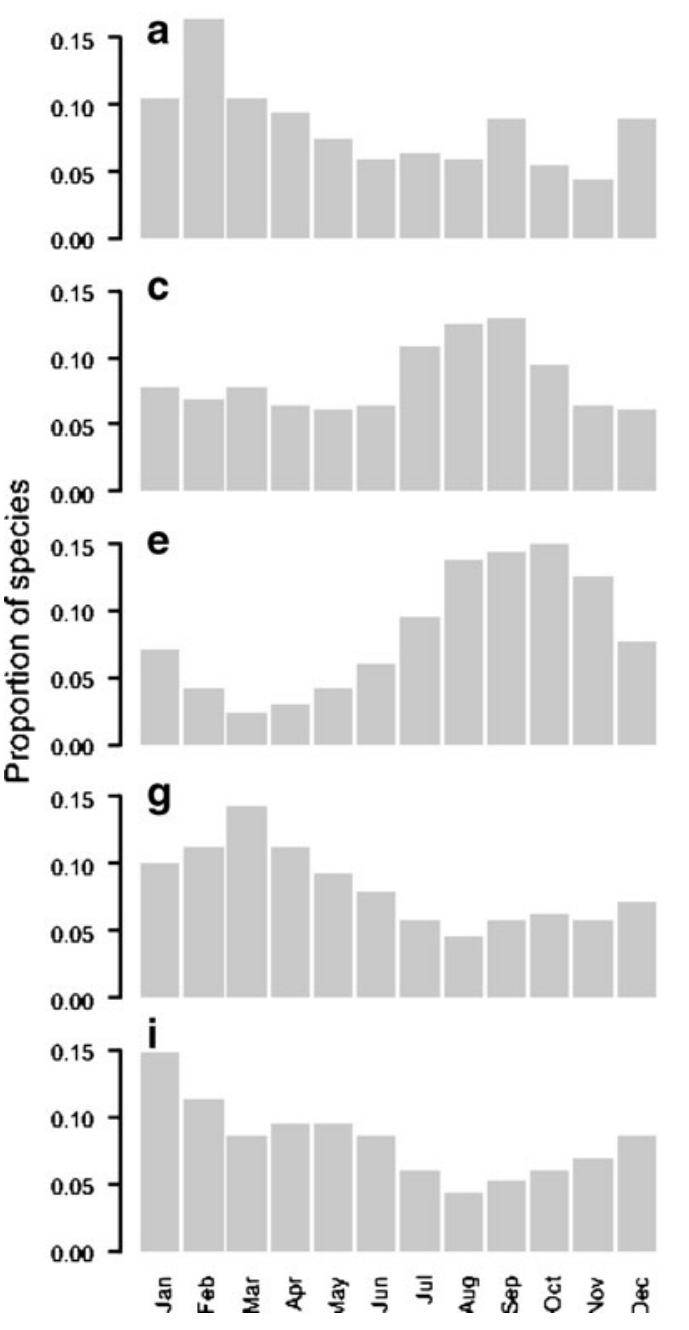

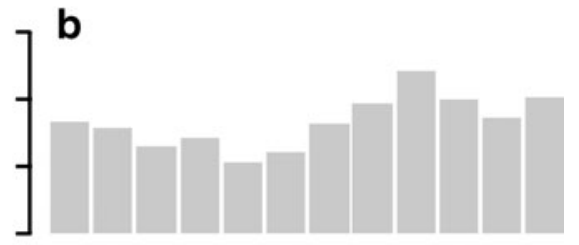
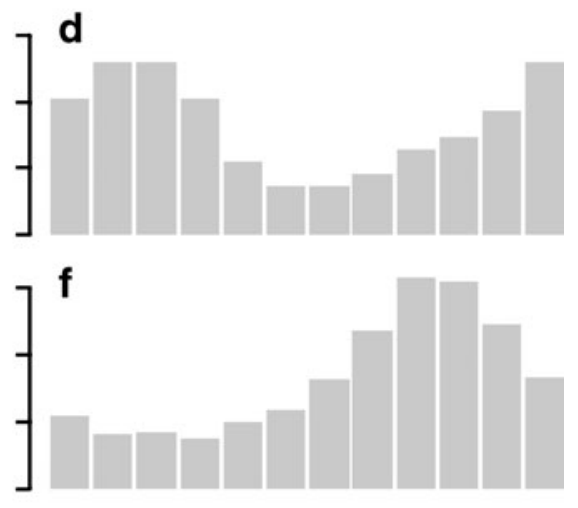

$h$
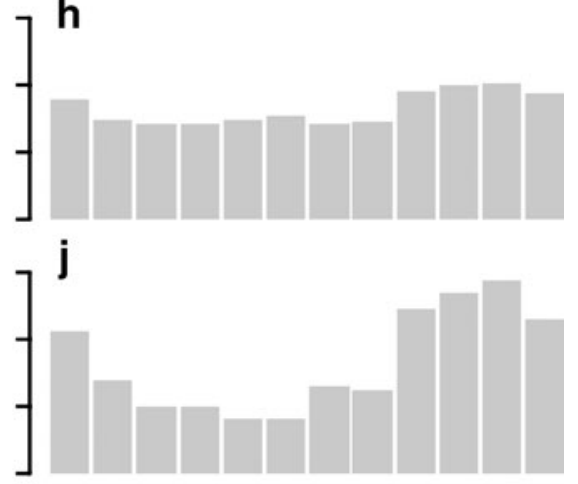

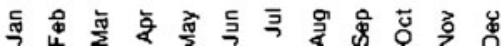

day length as a determinant of peaks in flowering of plant communities in cerrado and riparian forests (Table 3). Thus, sun-related variables may also explain the reproductive peaks in plant communities where species have access to water during most of the year, such as those in riparian forests.
4.3 Comparisons between woody and herbaceous component

We observed in the cerrado sites (1) reproductive peaks of woody species at the end of the dry season-beginning of the wet season and (2) reproductive peaks of herbaceous

Table 2 Rayleigh test of uniformity ( $Z$ ), mean angles (in degrees) of flowering and fruiting periods and the months that correspond to the average of the reproductive period distributions in cerrado and riparian forest sites in southeastern and central Brazil

\begin{tabular}{llllcrrr}
\hline Region & Vegetation type & Component & Phenological data & Mean angle & Month & $Z$ & P \\
\hline Southeastern & Cerrado & Herbaceous & Flowering & 52.9 & February & 0.188 & 0.001 \\
Southeastern & Cerrado & Herbaceous & Fruiting & 73.1 & March & 0.223 & 0.001 \\
Southeastern & Cerrado & Woody & Flowering & 290.3 & October & 0.136 & 0.001 \\
Southeastern & Cerrado & Woody & Fruiting & 309.3 & November & 0.087 & 0.017 \\
Southeastern & Swamp forest & Herbaceous & Flowering & 30 & January & 0.272 & 0.001 \\
Southeastern & Swamp forest & Herbaceous & Fruiting & 53.9 & February & 0.194 & 0.013 \\
Southeastern & Swamp forest & Woody & Flowering & 267.8 & September & 0.369 & 0.001 \\
Southeastern & Swamp forest & Woody & Fruiting & 309.9 & November & 0.299 & 0.001 \\
Central & Cerrado & Woody & Flowering & 198.7 & August & 0.131 & 0.001 \\
Central & Gallery forest & Woody & Flowering & 238.8 & September & 0.389 & 0.001 \\
\hline
\end{tabular}


Table 3 Correlation test between the number of flowering herbaceous and woody species in cerrado and riparian forests and both monthly rainfall and day length, in southeastern and central Brazil. Significant values of $\mathrm{R}^{2}$ are in bold $(\alpha=0.05)$

\begin{tabular}{|c|c|c|c|c|c|c|c|c|}
\hline \multirow[t]{2}{*}{ Region } & \multirow[t]{2}{*}{ Vegetation type } & \multirow[t]{2}{*}{ Component } & \multicolumn{3}{|c|}{ Rainfall } & \multicolumn{3}{|c|}{ Day length } \\
\hline & & & $R^{2}$ & $t$ & $P$ & $R^{2}$ & $t$ & $P$ \\
\hline Southeastern & Cerrado & Herbaceous & 0.25 & 1.82 & 0.10 & 0.06 & 0.82 & 0.43 \\
\hline Southeastern & Cerrado & Woody & 0.06 & 0.78 & 0.45 & 0.31 & 2.19 & 0.05 \\
\hline Southeastern & Swamp forest & Herbaceous & 0.73 & 5.26 & 0.01 & 0.45 & 2.87 & 0.02 \\
\hline Southeastern & Swamp forest & Woody & 0.03 & 0.55 & 0.59 & 0.23 & 1.75 & 0.11 \\
\hline Central & Cerrado & Woody & 0.2 & -1.60 & 0.14 & 0.07 & -0.87 & 0.41 \\
\hline Central & Gallery forest & Woody & 0.07 & -0.91 & 0.38 & 0.01 & 0.21 & 0.84 \\
\hline
\end{tabular}

species at the end of the wet season, as in other studies (Batalha and Mantovani 2000; Batalha and Martins 2004). Thus, the climatic seasonality provides a potential axis of niche separation by phenology for the herbaceous and woody plants in cerrado (Scholes and Archer 1997). It has been argued that this phenological separation is due to the differential moisture availability for woody and herbaceous species (Batalha and Martins 2004; Sarmiento and Monasterio 1983). Whereas the woody component is predominantly deep rooted and can reach soil layers where water is available (Oliveira et al. 2005), the herbaceous component depends on the rainy season, when the species gradually develop their shoots and reproductive structures (Sarmiento and Monasterio 1983). However, the phenological pattern that we observed in riparian forests does not support this expectation. The reproductive peaks were similar to those observed in cerrado sites, even though riparian forest soils do not experience extensive water shortage (Naiman and Décamps 1997). Again, annual variation in sun-related environmental factors may explain the observed patterns in both riparian forest and cerrado sites (Morellato et al. 2000; Borchert et al. 2005).

We did not observe a flowering pattern among species of the same component in both cerrado and riparian forests, even when considering the components under the same regional climate. In a seasonal tropical forest, differences of microhabitat, such as water and light conditions, are related to distinct patterns of flowering and fruiting at the same regional climate (Thies and Kalko 2004). Future studies should investigate the influence of microclimatic variables over the reproductive events in cerrado and riparian forests. However, in southeastern sites, the flowering peaks in the riparian forest occurred before those in the cerrado, reinforcing that the plants in riparian forest are independent from the first rains to flowering, especially the herbaceous species with shallow roots (Sarmiento and Monasterio 1983).

\subsection{Fruiting peaks}

The fruiting peaks were similar in cerrado and riparian forest. The peaks of fruiting in the wet season suggest an overall ecological strategy of plants in both vegetation types to improve the germination success, by dispersing fruits and releasing seeds during wetter soil conditions. Thus, germination success seems to be the ultimate cause of fruiting synchronization, but the onset of the wet season is the proximate cue. Oliveira (2008) has observed that cerrado species with distinct fruiting periods synchronise the seed germination and seedling establishment to the beginning of the rainy season. In this case, species that release their seeds at the end of the wet season or during the dry season keep them dormant until the beginning of the next rainy season (Oliveira 2008). This adjustment maximises the survival of the seedling that has the entire rainy season to grow. Accordingly, the water shortage in the dry season seems to be a stronger selective force for synchronisation of germination than for synchronization of fruiting. In riparian forests, however, the water shortage may be not a selective force and the adjustment of the germination is not predicted.

\subsection{Phylogenetic signal}

The phylogenetic signal in reproductive events has been found in several tropical plant communities (Boulter et al. 2006; Kochmer and Handel 1986; Staggemeier et al. 2010; Wright and Calderon 1995). Phylogenetic signals seem to be a characteristic of plant traits related to environmental tolerances, such as light, soil moisture and pH (Prinzing et al. 2001). These traits are associated with habitat requirements and consequently they define the ' $\beta$ niche' of the species, referring to the scale at which $\beta$ diversity is determined (Silvertown et al. 2006). However, absence of phylogenetic signal in traits that determine within-habitat $\alpha$-diversity ( $\alpha$ niche) may also be common (Silvertown et al. 2006), because $\alpha$ niches define the species interactions within a community and therefore are expected to be different for species to coexist (Silvertown et al. 2006). Nevertheless, evidence of overdispersion of reproductive periods that would indicate a mechanism of coexistence is generally little (Boulter et al. 2006). Thus, our results supported the idea that the evolution of reproductive periods may be indeed random in relation 
to species phylogeny. In seasonal forests, flowering patterns of taxonomically related species are also not different from random (Stevenson et al. 2009). Thus, even if there is a phylogenetic signal in reproductive periods of tropical communities (Boulter et al. 2006; Staggemeier et al. 2010; Wright and Calderon 1995), it may have a lower importance in plant communities under marked seasonal variation.

Recently, Staggemeier et al. (2010) demonstrated the shared influence of environment and phylogeny on the reproductive events of Myraceae species, i.e. closely related plants flowered under similar climatic conditions. However, we did not find any evidence of phylogenetic conservatism of flowering and fruiting time in cerrado and riparian forest. Although the combined effect of environment and phylogeny is predicted to be present in other plant families (Staggemeier et al. 2010), at the community level, this effect may be hard to detect. The mixture of different phenological strategies in plant communities in cerrado (Monasterio and Sarmiento 1976; Sarmiento and Monasterio 1983) may hide the phylogenetic constrains present at smaller taxonomic scales.

\section{Conclusions}

The riparian forests showed peaks of flowering and fruiting similar to cerrado, in spite of the small seasonality in soil moisture availability. These peaks were partially explained by day length and rainfall. Therefore, sun-related factors may be the main cues for the phenology of species in both cerrado and riparin forest, as well as in other vegetation types (Morellato et al. 2000; Borchert et al. 2005). Nevertheless, the reproductive periods of plants under seasonal climatic variation may not be under phylogenetic constraints, as observed in nonseasonal plant communities (Wright and Calderon 1995) and in restricted taxonomic groups (Staggemeier et al. 2010). Climatic factors seem to be more important than phylogenetic history in determining the reproductive periods of plants in savannas and riparian forests. Further studies should search for phylogenetic constraints in phenological events and for correlations between climatic variables and reproductive periods in other vegetation types under seasonal climatic variation (for example, in grasslands) to corroborate our generalisation.

Acknowledgements We are grateful to $\mathrm{CNPq}$, for the scholarship granted to G.H.C. and M.A.B.; to Fapesp, for the scholarship granted to D.M.S. and I.A.S.; to M.W. Valenti, P.H. Silva, and P.P. Loiola, for helping us in field work; and to the taxonomist M.A. Pinho-Ferreira, for their assistance in species identification.

\section{References}

Batalha MA, Mantovani W (2000) Reproductive phenological patterns of cerrado plant species at the Pé-de-Gigante Reserve (Santa Rita do Passa Quatro, SP, Brazil): a comparison between the herbaceous and the woody floras. Braz J Biol 60:129-145

Batalha MA, Martins FR (2004) Reproductive phenology of the cerrado plant community in Emas National Park (central Brazil). Aust J Bot 52:149-161

Blomberg SP, Garland T Jr, Ives AR (2003) Testing for phylogenetic signal in comparative data: behavioral traits are more labile. Evolution 57:717-745

Borchert R, Rivera G, Hagnauer W (2002) Modification of vegetative phenology in a tropical semi-deciduous forest by abnormal drought and rain. Biotropica 34:27-39

Borchert R, Renner SS, Calle Z, Navarrete D, Tye A, Gautier L, Spichiger R, von Hildebrand P (2005) Photoperiodic induction of synchronous flowering near the Equator. Nature 433:627-629

Boulter SL, Kitching RL, Howlett BG (2006) Family, visitors and the weather: patterns of flowering in tropical rain forests of northern Australia. J Ecol 94:369-382

Cornelissen JHC, Lavorel S, Garnier E, Díaz S, Buchmann N, Gurbich DE, Reich PB, Steege H, Morgan HD, van der Heijden MGA, Pausas JG, Pooter H (2003) A handbook of protocols for standardized and easy measurement of plant fuctional trait worldwide. Aust J Bot 51:335-380

Davies TJ, Barraclough TG, Chase MW, Soltis PS, Soltis DE, Savolainen V (2004) Darwin's abominable mystery: insights from a supertree of the angiosperms. Proc Nat Acad Sci USA 101:1904-1909

Felfili JM, Mendonça RC, Walter BMT, Silva Júnior MC, Fagg CW, Nóbrega MGG, Sevilha AC, Silva MA (2001) Flora fanerogâmica das matas de galeria e ciliares do Brasil Central. In: Ribeiro JF, Fonseca CEL, Sousa-Silva JC (eds) Cerrado: caracterização e recuperação de Matas de Galeria. Embrapa, Planaltina, pp 195-263

Funch LS, Funch R, Barroso GM (2002) Phenology of gallery and montane forest in the Chapada Diamantina, Bahia, Brazil. Biotropica 34:40-50

Gottsberger G, Silberbauer-Gottsberger I (2006) Life in the cerrado: a South American tropical seasonal vegetation. Origin, structure, dynamics and plant use, vol 1. Reta Verlag, Ulm, p 277

Gouveia GP, Felfili JM (1998) Fenologia de comunidades de cerrado e de mata de galeria no Brasil Central. Rev Árvore 22:443-450

Kochmer JP, Handel SN (1986) Constraints and competition in the evolution of flowering phenology. Ecol Monogr 56:303-325

Köppen W (1931) Grundriss der Klimakunde. Gruyter, Berlin, p 338

Manly BFJ (2004) Multivariate statistical methods: a primer. Chapman \& Hall, New York, p 208

Mduma SAR, Sinclair ARE, Turkington R (2007) The role of rainfall and predators in determining synchrony in reproduction of savanna trees in Serengeti National Park, Tanzania. J Ecol 85:184-196

Monasterio M, Sarmiento G (1976) Phenological strategies of plant species in the tropical savanna and the semi-deciduous forest of the Venezuelan Llanos. J Biogeogr 3:325-355

Morellato LPC (2003) South America. In: Schwartz MD (ed) Phenology: an integrative environmental science. Kluwer Academic Publishers, Netherland, pp 75-92

Morellato LPC, Talora DC, Takahasi A, Bencke CC, Romera EC, Zipparro VB (2000) Phenology of Atlantic rain forest trees: a comparative study. Biotropica 32:811-823

Morellato LPC, Alberti LF, Hudson IL (2010) Applications of circular statistics in plant phenology: a case studies approach. In: Hudson IL, Keatley MR (eds) Phenological research: methods for 
environmental and climate change analysis. Springer, London, pp 339-359

Naiman RJ, Décamps H (1997) The ecology of interfaces: riparian zones. Annu Rev Ecol Syst 28:621-658

Oliveira PEAM (2008) Fenologia e biologia reprodutiva das espécies de cerrado. In: Sano SM, Almeida SP, Ribeiro JF (eds) Cerrado: ecologia e flora. Embrapa, Brasília, pp 273-287

Oliveira PE, Gibbs PE (2000) Reproductive biology of woody plants in a cerrado community of Central Brazil. Flora 195:311-329

Oliveira PE, Paula FR (2001) Fenologia e biologia reprodutiva de plantas de matas de galeria. In: Ribeiro JF, Fonseca CEL, Souza-Silva JC (eds) Cerrado: caracterização e recuperação de matas de galeria. Embrapa, Planaltina, pp 302-375

Oliveira RS, Bezerra L, Davidson EA, Pinto F, Klink CA, Nepstad DC, Moreira A (2005) Deep root function in soil water dynamics in cerrado savannas of central Brazil. Funct Ecol 19:574-581

Prinzing A, Durka W, Klotz S, Brandl R (2001) The niche of higher plants: evidence for phylogenetic conservatism. Proc R Soc Lond B 268:2383-2389

Qian H, Ricklefs RE (2004) Geographical distribution and ecological conservatism of disjunct genera of vascular plants in eastern Asia and eastern North America. J Ecol 92:253-265

Rathcke B, Lacey EP (1985) Phenological patterns of terrestrial plants. Ann Rev Ecol Syst 16:179-214

Sakai S (2001) Phenological diversity in tropical forests. Popul Ecol 43:77-86

Sarmiento G, Monasterio M (1983) Life forms and phenology. In: Goodall DW (ed) Ecosystems of the world-tropical savannas. Elsevier, Amsterdam, pp 79-108
Scholes RJ, Archer SR (1997) Tree-grass interactions in savannas. Ann Rev Ecol Syst 28:517-544

Silvertown J, McConway K, Gowing D, Dodd M, Fay MF, Joseph JA, Dolphin K (2006) Absence of phylogenetic signal in the niche structure of meadow plant communities. Proc Royal Soc Lond B 273:39-44

Staggemeier VG, Diniz-Filho JAF, Morellato LPC (2010) The shared influence of phylogeny and ecology on the reproductive patterns of Myrteae (Myrtaceae). J Ecol 98:1409-1421

Stevenson PR, Castellanos MC, Cortés AI, Link A (2009) Flowering patterns in a seasonal tropical lowland forest in western Amazonia. Biotropica 40:559-567

Thies W, Kalko EKV (2004) Phenology of neotropical pepper plants (Piperaceae) and their association with their main dispersers, two short-tailed fruit bats, Carollia perspicillata and C. castanea (Phyllostomidae). Oikos 104:362-376

van Schaik CP, Terborgh JW, Wright SJ (1993) The phenology of tropical forests: adaptive significance and consequences for primary consumers. Ann Rev Ecol Syst 24:353-377

Webb CO, Donoghue MJ (2005) Phylomatic: tree assembly for applied phylogenetics. Mol Ecol Notes 5:181-183

Williams RJ, Myers BA, Eamus D, Duff GA (1999) Reproductive phenology of woody species in a north Australian tropical savanna. Biotropica 31:626-636

Wright SJ, Calderon O (1995) Phylogenetic patterns among tropical flowering phenologies. J Ecol 83:937-948

Wright SJ, Cornejo FH (1990) Seasonal drought and leaf fall in a tropical forest. Ecology 71:1165-1175

Zar JH (1999) Biostatistical analysis. Prentice-Hall, Upper Saddle River, p 929 